\title{
ANALISIS CREDIT SCORING TERHADAP STATUS PEMBAYARAN BARANG ELEKTRONIK DAN FURNITURE MENGGUNAKAN BOOTSTRAP AGGREGATING K-NEAREST NEIGHBOR
}

\section{Credit Scoring Analysis of Payment Status of Electronic Goods and Furniture Using Bootstrap Aggregating K-Nearest Neighbor}

\author{
Putri Sri Astuti $^{1 *}$, Memi Nor Hayati ${ }^{2}$, Rito Goejantoro ${ }^{3}$ \\ ${ }^{1,2,3}$ Prodi Statistika, Fakultas Matematika dan Ilmu Pengetahuan Alam, Universitas Mulawarman \\ Jl. Barong Tongkok No.04, Samarinda, 75123, Indonesia \\ Corresponding author e-mail: 1* putrisastuti1@gmail.com
}

\begin{abstract}
Abstrak
Klasifikasi merupakan proses pengelompokan objek yang memiliki karakteristik sama ke dalam beberapa kategori. Penelitian ini menerapkan kombinasi algoritma klasifikasi, yaitu Bootstrap Aggregating K-Nearest Neighbor pada analisis credit scoring. Tujuannya adalah untuk mengklasifikasikan status pembayaran kredit barang elektronik dan furniture di PT KB Finansia Multi Finance tahun 2020 dan mengetahui tingkat akurasi yang dihasilkan. Status pembayaran kredit dikelompokkan dalam 2 kategori, yaitu lancar dan tidak lancar. Terdapat 7 variabel bebas yang digunakan sebagai gambaran karakteristik debitur, yaitu usia, jumlah tanggungan, lama tinggal, masa kerja, pendapatan, besar pembayaran, dan jangka pembayaran. Penerapan algoritma klasifikasi pada analisis credit scoring diharapkan dapat membantu pihak kreditur dalam mengambil keputusan menerima atau menolak pengajuan kredit dari calon debitur. Hasil penelitian menunjukkan bahwa akurasi yang diperoleh dari algoritma Bootstrap Aggregating $K$-Nearest Neighbor dengan proporsi $90: 10, m=80 \%, C=73$, dan $\mathrm{K}=5$ adalah yang terbaik, yaitu sebesar $92,308 \%$.
\end{abstract}

Kata Kunci : Klasifikasi, K-Nearest Neighbor, Bootstrap Aggregating, Kredit

\begin{abstract}
Classification is the process of grouping objects that have the same characteristics into several categories. This study applies a combination of classification algorithms, namely Bootstrap Aggregating K-Nearest Neighbor in credit scoring analysis. The aim is to classify the credit payment status of electronic goods and furniture at PT KB Finansia Multi Finance in 2020 and determine the level of accuracy produced. Credit payment status is grouped into 2 categories, namely smoothly and not smoothly. There are 7 independent variables that are used to describe the characteristics of the debtor, namely age, number of dependents, length of stay, years of service, income, amount of payment, and payment period. The application of the classification algorithm at the credit scoring analysis is expected to assist creditors in making decisions to accept or reject credit applications from prospective debtors. The results showed that the accuracy obtained from the Bootstrap Aggregating K-Nearest Neighbor algorithm with a proportion of $90: 10, m=80 \%, C=73$, and $K=5$ was the best, which was $92.308 \%$.
\end{abstract}

Keywords: classification, $k$-nearest neighbor, bootstrap aggregating, credit. 


\section{PENDAHULUAN}

Berbagai bidang usaha tentunya memiliki data besar yang berkaitan dengan produk, konsumen, maupun sistem pelayanannya. Sebagai bentuk upaya pengolahan data tersebut menjadi informasi yang lebih bermanfaat, maka muncullah beragam algoritma data mining. Pemilihan algoritma yang akan digunakan dapat disesuaikan dengan tugas atau tujuan pengerjaannya, misalnya untuk klasifikasi. Klasifikasi merupakan proses untuk memperkirakan kelompok objek baru, dimana kelasnya belum diketahui, dengan cara menggali model yang dapat menjelaskan atau membedakan kelas pada suatu kelompok data [1]. Dalam proses klasifikasi terdapat dua pekerjaan utama yang dilakukan, yaitu learning dan klasifikasi. Pada tahap learning, algoritma akan menganalisis data yang kelasnya sudah diketahui. Kemudian dilakukan representasi dalam bentuk rule klasifikasi. Rule yang diperoleh akan digunakan untuk mengklasifikasikan kelas dari data baru [2]. Algoritma sederhana yang biasa digunakan dalam klasifikasi adalah K-Nearest Neighbor (K-NN). K-NN bertujuan mengklasifikasikan data testing berdasarkan kedekatan jarak antara data training dengan data testing tersebut. Hal ini dilakukan dengan mencari beberapa kelompok objek dalam data training yang paling mirip dengan objek baru pada data testing [3]. Semakin dekat jarak data training ke data testing mengindikasikan bahwa semakin besar kemiripan yang dimiliki oleh keduanya. Dalam proses klasifikasi sering kali melibatkan kombinasi algoritma dengan tujuan peningkatan akurasi hasil prediksi, seperti Bootstrap dan Aggregating (Bagging) yang dilakukan oleh Breiman pada tahun 1996. Bagging dirancang untuk meningkatkan hasil klasifikasi melalui kombinasi acak pada set data training serta dapat mengurangi variansi dan menghindari overfitting [4]. Beberapa penelitian telah menerapkan Bagging pada algoritma klasifikasi tunggal seperti K-NN dengan pendekatan model average.

Bagging K-NN dapat diterapkan di kehidupan sehari-hari, termasuk dalam bidang pengkreditan. Banyaknya jumlah pengajuan kredit, disertai dengan beragamnya karakter debitur, menuntut pihak kreditur memiliki pertimbangan yang tepat. Oleh sebab itu diperlukan suatu analisis untuk memprediksi apakah seorang debitur baru dapat melakukan pembayaran kredit dengan lancar atau tidak. Dalam hal ini berbagai perusahaan di bidang pengkreditan telah menerapkan evaluasi kredit atau dikenal dengan penilaian kredit (credit scoring), sebagai bahan pertimbangan untuk menerima pengajuan kredit dari calon debitur. Sejalan dengan kemajuan teknologi informasi yang pesat maka perusahaan pengkreditan mulai menerapkan model statistik dalam mengevaluasi kredit. Salah satunya dengan mengembangkan analisis credit scoring dengan menerapkan algoritma klasifikasi. Credit scoring adalah tahap mengevaluasi pengajuan kredit dari calon debitur dengan segala atribut yang dimiliki. Model credit scoring dibangun menggunakan sampel kredit masa lalu dan kemudian dibagi menjadi 2 kelas, yaitu kredit baik (pembayaran dilakukan tepat waktu) dan kredit bermasalah (pembayaran dilakukan tidak tepat waktu). Kombinasi karakteristik debitur diperoleh berdasarkan pola sampel masa lalu sehingga dapat membedakan debitur yang baik dan buruk [5].

Berdasarkan uraian tersebut, penulis tertarik melakukan penelitian untuk mengklasifikasikan status pembayaran kredit barang elektronik dan furniture di PT KB Finansia Multi Finance tahun 2020 dan mengetahui tingkat akurasi yang dihasilkan. Penerapan algoritma klasifikasi pada tahap analisis credit scoring diharapkan dapat membantu pihak kreditur dalam mengambil keputusan menerima atau menolak pengajuan kredit dari calon debitur. Dalam penelitian ini digunakan proporsi

\section{METODE PENELITIAN}

Penelitian ini menerapkan algoritma Bootstrap Aggregating K-Nearest Neighbor (Bagging K-NN) pada sampel data debitur yang melakukan pelunasan kredit di tahun 2020. Teknik purposive sampling digunakan untuk pengambilan data dengan pertimbangan berkaitan dengan ketersediaan data terbaru.

\subsection{K-Nearest Neighbor}

Algoritma K-Nearest Neighbor (K-NN) termasuk dalam algoritma supervised learning. Tujuan algoritma supervised learning adalah menemukan pola atau fungsi baru yang dapat memetakan input ke output yang sesuai [6]. Dasar utama dari algoritma K-NN adalah kedekatan jarak suatu data testing ke data training. Nilai jarak tersebut digunakan sebagai ukuran kedekatan atau kemiripan. Algoritma ini bekerja dengan mencari nilai $\mathrm{K}$ terdekat berdasarkan pola input dan kemudian menentukan kelas keputusan [7]. Nilai $\mathrm{K}$ menunjukkan jumlah data training yang terdekat dengan data testing. Misalnya apabila K bernilai 1, maka akan diambil 1 tetangga terdekat dari data training. Apabila K bernilai 3, maka akan diambil 3 tetangga 
terdekat dari data training, begitu seterusnya. Jika dalam $\mathrm{K}$ tetangga terdekat terdapat dua kelas berbeda, maka kelas data testing akan ditentukan berdasarkan jumlah terbanyak atau melalui voting [8].

Jauh atau dekatnya jarak antara data testing dan data training dapat dihitung dengan perhitungan jarak Euclid. Semakin besar nilai yang diperoleh maka semakin jauh tingkat kemiripan antara data testing dan data training. Sebaliknya jika semakin kecil nilai yang diperoleh, maka semakin tinggi tingkat kemiripannya [9]. Rumus jarak Euclid dapat dilihat melalui Persamaan (1) [10]:

$$
d_{(a, b)}=\sqrt{\sum_{g=1}^{p}\left(x_{a, g}-x_{b, g}\right)^{2}}
$$

Keterangan:

$d_{(a, b)}:$ jarak Euclid antara data training ke- $a$ dengan data testing ke- $b$

$x_{a, g}:$ nilai data training ke- $a$ pada variabel ke- $g$

$x_{b, g} \quad$ : nilai data testing ke- $b$ pada variabel ke- $g$

$p \quad$ : banyak variabel bebas

Variabel dalam klasifikasi harus distandarisasi apabila memungkinkan untuk menghindari masalah yang akan dihasilkan dari penggunaan nilai skala yang berbeda antar variabel dalam klasifikaasi. Setelah dilakukan standarisasi, semua variabel akan berada dalam jangkauan yang sama sehingga proporsi pengaruh pada fungsi dalam klasifikator seimbang [1]. Pencarian nilai rata-rata seperti dalam Persamaan (2) dan juga nilai simpangan baku seperti Persamaan (3) akan digunakan untuk menghitung standarisasi suatu nilai seperti dalam Persamaan (4).

$$
\begin{gathered}
\bar{x}_{g}=\frac{1}{n} \sqrt{\sum_{j=1}^{n} x_{j, g}} \\
S_{\mathrm{g}}=\sqrt{\frac{1}{n-1} \sum_{\mathrm{j}=1}^{\mathrm{n}}\left(x_{(j, g)}-\bar{x}_{g}\right)^{2}} \\
x_{(j, g)}^{\prime}=\frac{x_{(j, g)}-\overline{\bar{x}}_{g}}{s_{g}}
\end{gathered}
$$

Keterangan:

$n \quad$ : jumlah data

$x_{j, g} \quad$ : data ke-j pada variabel ke- $g$

$\overline{\mathrm{x}}_{\mathrm{g}} \quad$ : rata-rata data pada variabel ke- $g$

$s_{g} \quad$ : simpangan baku variabel ke- $g$

$x_{(j, g)}^{\prime}:$ standarisasi data ke-j pada variabel ke- $g$

\subsection{Bootstrap Aggregating}

Bootstrap Aggregating atau biasa disebut dengan Bagging merupakan salah satu teknik yang diusulkan oleh Breiman pada tahun 1996 dan sering digunakan pada beberapa algoritma klasifikasi ataupun regresi untuk mereduksi variansi dari suatu variabel terikat, sehingga dapat memperbaiki proses pendugaan [11]. Penggunaan Bagging sangat membantu terutama untuk mengatasi sifat ketidakstabilan klasifikasi dan pohon regresi. Pada banyak gugus data yang dicoba, Bagging mampu mengurangi tingkat kesalahan pada kasus klasifikasi [10].

Bootstrap pertama kali digunakan oleh Efron pada tahun 1979. Metode ini didasari teknik resampling yaitu pengambilan data sampel secara berulang dan sifatnya saling bebas. Dari pengulangan tersebut akan diestimasi tingkat kesalahannya. Dalam hal ini sampel diambil secara acak dengan pengembalian [12]. Penentuan batas replikasi pada Bootstrap ditetapkan apabila hasil replikasi Bootstrap sudah menghasilkan nilai akurasi yang tinggi. Peningkatan akurasi dan prediksi akan terjadi jika banyaknya replikasi berkisar pada 
50 hingga 100 kali replikasi. Namun jika replikasinya ditingkatkan melebihi 100 kali, biasanya akan menghasilkan nilai akurasi yang tidak lebih besar dari nilai akurasi pada replikasi 50 hingga 100 kali [13]. Penelitian Breiman menunjukkan bahwa pengulangan dapat dilakukan 50 kali untuk kasus klasifikasi dan 25 kali untuk kasus regresi sehingga memperoleh hasil yang memuaskan. Selanjutnya dalam tahapan Aggregating dilakukan prediksi gabungan berdasarkan $B$ buah klasifikasi tersebut dengan menggunakan aturan majority vote [10]. Adapun tahapan Bagging adalah sebagai berikut [14]:

1. Melakukan Bootstrap sebanyak $m$ dari sejumlah $n$ data training. Hasil replikasi Bootstrap $X^{c}$ diulangi untuk $c=1,2, \ldots, C$, di mana $m$ adalah banyak data yang diambil dari data training, $n$ adalah banyaknya data training, dan $C$ adalah banyaknya replikasi Bootstrap yang dilakukan.

2. Menggunakan simple majority vote yaitu memilih kategori yang paling banyak muncul dari hasil penilaian sebagai aturan untuk pengambilan keputusan akhir.

\subsection{Confusion Matrix}

Proses prediksi yang dilakukan diharapkan mampu melakukan klasifikasi semua data set dengan benar, tetapi tidak dapat dipungkiri jika kinerja suatu sistem tidak $100 \%$ benar sehingga perlu dilakukan pengukuran kinerja klasifikasi. Confusion matrix atau matriks konfusi merupakan salah satu cara yang biasanya digunakan untuk mengukur kinerja suatu algortima klasifikasi. Pada dasarnya confusion matrix mengandung informasi yang membandingkan hasil klasifikasi yang dilakukan dengan hasil klasifikasi sebenarnya [8]. Nilai yang dihasilkan pada confusion matrix adalah berupa evaluasi kinerja algoritma yang dapat dilihat dari nilai accuray. Nilai Accuracy merupakan persentase jumlah record data yang diklasifikasikan secara benar oleh algoritma [15]. Perhitungan nilai Accuracy terdapat pada Persamaan (5).

$$
\text { Accuracy }=\frac{T P+T N}{P+N} \times 100 \%
$$

\subsection{Variabel Penelitian}

Variabel yang digunakan dalam penelitian ini terdiri atas variabel terikat yaitu status pembayaran kredit dari debitur dan tujuh variabel bebas yaitu usia, jumlah tanggungan, lama tinggal, masa kerja, pendapatan, besar pembayaran, dan jangka pembayaran. Status pembayaran kredit yang digunakan dikelompokkan dalam dua kelas, yakni status lancar (L) dan tidak lancar (TL).

\subsection{Tahap Analisis}

Tahap analisis yang dilakukan adalah sebagai berikut:

i Standarisasi data menggunakan Persamaan (4)

ii Pengacakan data

iii Membagi data training dan data testing

iv Menghitung jarak data training dan data testing

v Melakukan klasifikasi berdasarkan tetangga terdekat

vi Memilih proporsi terbaik

vii Penerapan Bootstrap

viii Penerapan Aggregating

ix Menghitung ketepatan akurasi algoritma

\section{HASIL DAN PEMBAHASAN}

Data yang digunakan berjumlah 133 data, yaitu D1 hingga D133. Sebelum masuk ke dalam tahap analisis, terlebih dahulu dilakukan standarisasi menggunakan Persamaan (4). tujuannya agar semua data pada setiap variabel berada dalam jangkauan yang sama. Dengan demikian proporsi pengaruh tiap variabel pada fungsi klasifikator dapat seimbang. Setelah standarisasi data, maka tahap selanjutnya adalah pengacakan data. Pengacakan data dalam penelitian ini dilakukan dengan menggunakan software $R$. Adapun tujuan dari pengacakan ini, yaitu agar setiap data memiliki kesempatan yang sama untuk menjadi data training atau data testing. Data hasil pengacakan akan dibagi menjadi data training dan data testing dengan menggunakan tiga proporsi, yaitu 50:50, 70:30, dan 90:10. Ketiga proporsi akan diterapkan pada tahap analisis yang sama. Peneliti menggunakan proporsi 90:10 sebagai contoh untuk menguraikan perhitungan dalam analisis. 
Penggunaan proporsi 90:10 bermakna bahwa 90\% data dari hasil pengacakan yang berada di urutan awal akan menjadi data training, sedangkan $10 \%$ data di urutan selanjutnya akan menjadi data testing. Sehingga diperoleh 120 data training dan 13 data testing.

\subsection{Perhitungan Jarak Euclid}

Jarak Euclid digunakan untuk menghitung jarak data training ke setiap data testing. Perhitungan jarak Euclid dilakukan dengan menggunakan Persamaan (1). Jarak antara semua data training dengan data testing pertama yaitu D90 akan dihitung seperti berikut.

$$
\begin{aligned}
& d_{1,1}=\sqrt{\left((-0,997)-(-0,450)^{2}+((-1,829)-(-0,036))^{2}+\cdots+((0,365)-(0,365))^{2}\right.} \\
& =2,559 \\
& d_{2,1}=\sqrt{((-0,450)-(-0,450))^{2}+((1,159)-(-0,036))^{2}+\cdots+((0,365)-(0,365))^{2}} \\
& \quad=1,646 \\
& \vdots \\
& d_{120,1}=\sqrt{((-0,778)-(-0,450))^{2}+((-0,634)-(-0,036))^{2}+\cdots+((-0,663)-(0,365))^{2}} \\
& =2,053
\end{aligned}
$$

Perhitungan jarak Euclid dilanjutkan hingga data training ke-120 (D109) dengan data testing ke-13 (D25).

\subsection{Klasifikasi Status Pembayaran Kredit}

Jarak Euclid untuk masing-masing data testing diurutkan berdasarkan kedekatannya dengan data training. Setelah itu data testing diklasifikasikan berdasarkan nilai $\mathrm{K}$, dimana dalam penelitian ini digunakan $\mathrm{K}=1, \mathrm{~K}=3, \mathrm{~K}=5, \mathrm{~K}=7$, dan $\mathrm{K}=9$. Nilai $\mathrm{K}$ berfungsi sebagai batas $\mathrm{K}-\mathrm{NN}$ atau batas $\mathrm{K}$ tetangga terdekat. Apabila $\mathrm{K}$ awal yang digunakan adalah $1(1-\mathrm{NN})$, maka hasil klasifikasi data testing akan didasari pada kelas dari 1 tetangga terdekat saja atau rank pertama. Apabila menggunakan batas 3 tetangga terdekat (3-NN),

\begin{tabular}{|c|c|c|c|c|c|}
\hline \multirow{2}{*}{ Rank } & \multicolumn{2}{|c|}{ Data Training } & \multirow{2}{*}{$\begin{array}{c}\text { Data testing } \\
\text { D90 } \\
d_{(\mathbf{a}, 90)}\end{array}$} & \multirow{2}{*}{ Batas K-NN } & \multirow{2}{*}{$\begin{array}{c}\text { Hasil Klasifikasi Data } \\
\text { Testing }\end{array}$} \\
\hline & Sampel & Klasifikasi & & & \\
\hline 1 & D18 & $\mathrm{L}$ & 0,729 & $1-\mathrm{NN}$ & $\mathrm{L}$ \\
\hline 2 & D126 & TL & 1,139 & & \\
\hline 3 & D94 & $\mathrm{L}$ & 1,157 & 3-NN & $\mathrm{L}$ \\
\hline 4 & D19 & $\mathrm{L}$ & 1,186 & & \\
\hline 5 & D110 & $\mathrm{L}$ & 1,191 & $5-\mathrm{NN}$ & $\mathrm{L}$ \\
\hline 6 & D46 & $\mathrm{L}$ & 1,272 & & \\
\hline 7 & $\mathrm{D} 23$ & $\mathrm{~L}$ & 1,340 & 7-NN & $\mathrm{L}$ \\
\hline 8 & D60 & $\mathrm{L}$ & 1,389 & & \\
\hline 9 & D120 & $\mathrm{TL}$ & 1,412 & 9-NN & $\mathrm{L}$ \\
\hline$\vdots$ & $\vdots$ & $\vdots$ & $\vdots$ & & \\
\hline 120 & D34 & $\mathrm{TL}$ & 6,427 & & \\
\hline
\end{tabular}
maka hasil klasifikasi data testing akan didasari pada 3 tetangga terdekat, yaitu rank pertama sampai dengan rank ketiga dan kemudian dilakukan voting dari 3 kelas tetangga terdekat tersebut. Begitu pun seterusnya sampai menggunakan batas 9 tetangga terdekat $(9-\mathrm{NN})$. Peneliti menggunakan data testing pertama (D90) sebagai contoh untuk menguraikan rank jarak Euclid yang dapat dilihat pada Tabel 1.

Tabel 1. Rank Jarak Euclid Data Training dengan Data Testing D90

\subsection{Pemilihan Proporsi Terbaik}

Hasil klasifikasi kategori status pembayaran kredit untuk semua data testing akan dibandingkan dengan kategori sebenarnya (actual), sehingga dapat diketahui jumlah kesalahan klasifikasi di setiap nilai K. Semakin kecil jumlah kesalahan klasifikasi maka semakin besar kemungkinan nilai $\mathrm{K}$ tersebut menjadi nilai $\mathrm{K}$ optimal. 
Selanjutnya untuk memilih proporsi terbaik dapat dilakukan dengan melihat dari nilai akurasi klasifikasi yang dihasilkan menggunakan Persamaan (5). Secara keseluruhan akurasi untuk setiap nilai K pada masing-masing proporsi dapat dilihat dalam Tabel 2. Kemudian akurasi tersebut akan dibandingkan dan dipilih yang terbaik (nilai akurasi tertinggi) untuk digunakan dalam tahap selanjutnya.

Tabel 2. Akurasi Setiap Nilai K pada Proporsi yang Berbeda Proporsi Data Training dan Data

\begin{tabular}{cccc} 
K-NN & \multicolumn{3}{c}{ Testing } \\
\cline { 2 - 4 } & $\mathbf{5 0 : 5 0}$ & $\mathbf{7 0 : 3 0}$ & $\mathbf{9 0 : 1 0}$ \\
\hline 1-NN & $66,667 \%$ & $69,231 \%$ & $76,923 \%$ \\
\hline 3-NN & $66,667 \%$ & $69,231 \%$ & $76,923 \%$ \\
\hline 5-NN & $68,182 \%$ & $69,231 \%$ & $76,923 \%$ \\
\hline 7-NN & $74,242 \%$ & $66,667 \%$ & $84,615 \%$ \\
\hline 9-NN & $75,758 \%$ & $71,795 \%$ & $92,308 \%$
\end{tabular}

Berdasarkan Tabel 2 diketahui bahwa akurasi tertinggi terdapat pada penggunaan proporsi 90:10, yaitu sebesar $92,308 \%$. Hal ini berarti data yang akan digunakan dalam tahap selanjutnya adalah data dengan pembagian proporsi 90:10, yakni terdapat 120 data training dan 13 data testing.

\subsection{Penerapan Bootstrap}

Tahap ini didasari pada pengambilan sampel secara berulang (resampling) disertai pengembalian, sehingga memungkinkan sampel terambil lebih dari satu kali. Hal pertama yang perlu dilakukan yaitu mengambil sampel secara acak dari data training untuk menjadi data Bootstrap sebanyak $m \%$ dari jumlah data training. Proporsi 90:10 terpilih pada sub bab 4.5 karena memiliki nilai akurasi tertinggi, sehingga jumlah data Bootstrap yang akan diambil adalah $(m \% \times 120)$ data. Kemudian data bootstrap dijadikan sebagai data training untuk mengklasifikasikan kembali 13 data testing dengan menggunakan tahapan yang sama seperti pada tahap K-NN. Setelah itu tahap resampling hingga tahap klasifikasi diulangi sebanyak $C$ kali. Dalam hal ini, akan diperoleh hasil klasifikasi data testing sebanyak $C$.

Penelitian ini menggunakan $m=50 \%, m=60 \%, m=70 \% m=80 \%, m=90 \%$, dan $m=100 \%$. Adapun nilai $C$ dipilih secara acak sebanyak 10 dari rentang 30 hingga 120 . Berdasarkan hasil pengacakan diperoleh 10 nilai $C$ yang digunakan, yaitu $31,45,51,57,67,73,79,85,99$, dan 107. Proses klasifikasi menggunakan nilai $\mathrm{K}=1, \mathrm{~K}=3, \mathrm{~K}=5, \mathrm{~K}=7$, dan $\mathrm{K}=9$. Penggunaan nilai $m, C$, dan $\mathrm{K}$ dilakukan satu per satu dalam tahap klasifikasi. Kemudian dianalisis serta dipilih yang terbaik berdasarkan akurasi yang diperoleh. Peneliti menetapkan penggunaan $m=80 \%, C=73$, dan $\mathrm{K}=5$ sebagai contoh untuk menguraikan tahapan Bootstrap hingga perhitungan akurasi. Dengan demikian jumlah data Bootstrap yang diambil adalah sebanyak $(80 \% \times 120)$ data, yakni sebanyak 96 data. Pengulangan dilakukan sebanyak 73 kali dengan menggunakan batas 5-NN dalam proses klasifikasi. Data Bootstrap pertama dapat dilihat pada Tabel 3.

Tabel 3. Data Bootstrap pertama

\begin{tabular}{cccccccccc}
\hline \multirow{2}{*}{ No } & \multirow{2}{*}{ Sampel } & \multicolumn{7}{c}{ Variabel } \\
\cline { 3 - 10 } & & $\boldsymbol{Y}$ & $\boldsymbol{X}_{\boldsymbol{I}}$ & $\boldsymbol{X}_{\mathbf{2}}$ & $\boldsymbol{X}_{\mathbf{3}}$ & $\boldsymbol{X}_{4}$ & $\boldsymbol{X}_{5}$ & $\boldsymbol{X}_{\mathbf{6}}$ & $\boldsymbol{X}_{7}$ \\
\hline $\mathbf{1}$ & $\mathrm{D} 14$ & $\mathrm{TL}$ & 0,206 & $-0,036$ & $-0,713$ & 0,563 & 1,007 & 2,074 & 1,907 \\
\hline $\mathbf{2}$ & $\mathrm{D} 3$ & $\mathrm{~L}$ & $-0,122$ & 1,159 & 0,199 & $-0,905$ & $-0,85$ & $-0,268$ & $-1,177$ \\
\hline $\mathbf{3}$ & $\mathrm{D} 51$ & $\mathrm{TL}$ & 0,206 & 1,159 & 2,113 & 0,563 & $-0,85$ & 0,155 & 0,365 \\
\hline$\vdots$ & $\vdots$ & $\vdots$ & $\vdots$ & $\vdots$ & $\vdots$ & $\vdots$ & $\vdots$ & $\vdots$ & $\vdots$ \\
\hline $\mathbf{9 6}$ & $\mathrm{D} 73$ & $\mathrm{TL}$ & 0,863 & 1,159 & 1,110 & 0,122 & 1,316 & $-0,506$ & $-1,177$ \\
\hline
\end{tabular}

Data Bootstrap pertama akan berperan sebagai data training untuk mengklasifikasikan data testing. Tahapan klasifikasi dilakukan sama seperti pada tahapan klasifikasi K-NN tunggal. 


\subsubsection{Perhitungan Jarak}

Perhitungan jarak Euclid antara data training Bootstrap pertama dengan data testing D90 menggunakan Persamaan (1) dilakukan seperti berikut.

$$
\begin{aligned}
d_{1,1} & =\sqrt{((0,206)-(-0,450))^{2}+((-0,036)-(-0,036))^{2}+\cdots+((-1,907)-(0,365))^{2}} \\
& =3,457 \\
d_{2,1} & =\sqrt{((-0,122)-(-0,450))^{2}+((1,159)-(-0,036))^{2}+\cdots+((-1,177)-(0,365))^{2}} \\
& =2,545 \\
\vdots & \\
d_{120,1} & =\sqrt{((0,863)-(-0,450))^{2}+((1,159)-(-0,036))^{2}+\cdots+((-1,177)-(0,365))^{2}} \\
& =3,586
\end{aligned}
$$

Perhitungan jarak Euclid dilanjutkan hingga data training Bootstrap pertama ke-96 (D73) dengan data testing ke-13 (D25).

\subsubsection{Klasifikasi Status Pembayaran Kredit}

Jarak Euclid yang telah diperoleh untuk masing-masing data testing diurutkan berdasarkan kedekatannya dengan data training Bootstrap pertama. Setelah itu dilakukan klasifikasi status pembayaran menggunakan batas 5-NN. Peneliti menggunakan data testing D90 sebagai contoh untuk menampilkan rank jarak Euclid dan hasil klasifikasi yang dapat dilihat pada Tabel 4.

Tabel 4. Rank Jarak Euclid dan Hasil Klasifikasi Data Testing D90

\begin{tabular}{cccccc}
\hline \multirow{2}{*}{ Rank } & \multicolumn{2}{c}{ Data Training } & $\begin{array}{c}\text { Data Testing } \\
\text { D90 }\end{array}$ & Batas K-NN & $\begin{array}{c}\text { Hasil Klasifikasi } \\
\text { Data Testing }\end{array}$ \\
\cline { 2 - 4 } & Sampel & Klasifikasi & $\boldsymbol{d}_{(\mathbf{a}, 90)}$ & & \\
\hline $\mathbf{1}$ & D94 & L & 1,157 & & \\
\hline $\mathbf{2}$ & D19 & L & 1,186 & & \\
\hline $\mathbf{3}$ & D19 & L & 1,186 & & \\
\hline $\mathbf{4}$ & D110 & L & 1,191 & & \\
\hline $\mathbf{5}$ & D23 & L & 1,340 & 5-NN & \\
\hline$\vdots$ & $\vdots$ & $\vdots$ & $\vdots$ & & \\
\hline $\mathbf{9 6}$ & D34 & TL & 6,427 & & \\
\hline
\end{tabular}

Hasil klasifikasi menunjukkan status pembayaran untuk data testing D90 menggunakan 5-NN adalah lancar. Selanjutnya dilakukan resampling kedua dan seterusnya sampai dengan 73 kali. Data hasil resampling dijadikan sebagai data training Bootstrap yang digunakan untuk mengklasifikasikan setiap data testing. Dalam hal ini satu data testing memiliki 73 hasil klasifikasi berdasarkan data training Bootstrap.

\subsection{Penerapan Aggregating}

Setelah memperoleh 73 hasil klasifikasi untuk setiap data testing, maka langkah selanjutnya adalah menerapkan Aggregating. Langkah ini dilakukan untuk menentukan kategori status pembayaran akhir dari tiap data testing berdasarkan suara terbanyak (majority vote). Hasil majority vote dari Aggregating dapat dilihat pada Tabel 5. 
Tabel 5. Hasil Aggregating Data Testing dengan 5-NN

\begin{tabular}{|c|c|c|c|c|c|c|c|c|c|c|c|}
\hline \multirow{2}{*}{$\begin{array}{c}\text { Data } \\
\text { Testing }\end{array}$} & \multicolumn{8}{|c|}{ Hasil Klasfikasi Pengulangan Bootsrap ke- } & \multirow{2}{*}{$\mathbf{L}$} & \multirow{2}{*}{ TL } & \multirow{2}{*}{$\begin{array}{c}\text { Majority } \\
\text { Vote }\end{array}$} \\
\hline & 1 & 2 & 3 & 4 & ... & 71 & 72 & 73 & & & \\
\hline D90 & $\mathrm{L}$ & $\mathrm{L}$ & $\mathrm{L}$ & $\mathrm{L}$ & .. & $\mathrm{L}$ & $\mathrm{L}$ & $\mathrm{L}$ & 68 & 5 & $\mathrm{~L}$ \\
\hline D116 & $\mathrm{L}$ & $\mathrm{L}$ & $\mathrm{L}$ & TL & .. & $\mathrm{L}$ & $\mathrm{L}$ & TL & 57 & 16 & $\mathrm{~L}$ \\
\hline D133 & TL & $\mathrm{L}$ & $\mathrm{L}$ & $\mathrm{L}$ & .. & $\mathrm{L}$ & $\mathrm{L}$ & TL & 64 & 9 & $\mathrm{~L}$ \\
\hline$\vdots$ & $\vdots$ & $\vdots$ & $\vdots$ & $\vdots$ & $\ddots$ & $\vdots$ & $\vdots$ & $\vdots$ & $\vdots$ & $\vdots$ & $\vdots$ \\
\hline D25 & TL & TL & L & $\mathrm{L}$ & $\ldots$ & TL & TL & TL & 41 & 32 & $\mathrm{~L}$ \\
\hline
\end{tabular}

Berdasarkan 73 hasil Bootstrap menggunakan 5-NN diperoleh bahwa data testing D90 diklasifikasikan dalam kategori lancar sebanyak 68 kali dan dalam kategori tidak lancar sebanyak 5 kali. Sehingga dengan menerapkan majority vote dalam Aggregating maka klasifikasi akhir untuk data testing D90 adalah status pembayaran kredit lancar. Data testing D116 diklasifikasikan dalam kategori lancar sebanyak 57 kali dan kategori tidak lancar sebanyak 16 kali. Dengan demikian maka klasifikasi akhir untuk data testing D116 adalah status pembayaran kredit lancar. Data testing D133 diklasifikasikan dalam kategori lancar sebanyak 64 kali dan kategori tidak lancar sebanyak 9 kali. Klasifikasi akhir untuk data testing D133 adalah status pembayaran kredit lancar. Cara yang sama juga dilakukan untuk menentukan klasifikasi akhir dari data testing yang lainnya hingga data testing D25.

\subsection{Ketepatan Akurasi Algoritma}

Setelah memperoleh hasil klasifikasi untuk setiap data testing melalui tahap Aggregating, maka selanjutnya dilakukan perhitungan akurasi menggunakan Persamaan (5). Setelah memperoleh nilai akurasi, maka selanjutnya adalah mengulangi tahapan Bootstrap hingga perhitungan akurasi dengan menggunakan nilai $m, C$, dan $\mathrm{K}$ yang lain. Akurasi yang diperoleh akan dianalisis secara keseluruhan dan dipilih yang terbaik untuk mengklasifikasikan data testing. Peneliti melakukan analisis untuk memilih nilai $m$, $C$, dan $\mathrm{K}$ terbaik dengan beberapa pertimbangan, yaitu peningkatan akurasi dari nilai yang diperoleh pada Tabel 4.10 dan kekonsistenan akurasi yang ditinjau secara keseluruhan di setiap nilai $m$, $C$, dan K. Kekonsistenan ini menggambarkan bahwa hasil klasifikasi yang diperoleh dapat lebih dipercaya karena tidak berubah untuk setiap nilai $m, C$, dan $\mathrm{K}$ yang digunakan.

Berdasarkan pertimbangan tersebut, peneliti memilih penggunaan $\mathrm{K}=5$ dengan nilai $m=80 \%$ dan $C=73$ yang terbaik. Dengan demikian penerapan algoritma Bagging K-NN menggunakan proporsi 90:10, $m=80 \%$, $C=73$, dan $\mathrm{K}=5$ dalam analisis credit scoring barang elektronik dan furniture di PT KB Finansia Multi Finance menghasilkan akurasi terbaik, yakni sebesar 92,308\%. Algoritma ini dapat mengklasifikasikan status pembayaran kredit dari 12 debitur secara tepat dari 13 debitur yang status pembayarannya tepat diklasifikasikan, yaitu 10 debitur dengan status pembayaran lancar dan 2 debitur dengan status pembayaran tidak lancar. Adapun 1 debitur lainnya tidak tepat diklasifikasikan, yaitu debitur yang seharusnya memiliki status pembayaran lancar diklasifikasikan dalam kategori status pembayaran tidak lancar.

\section{KESIMPULAN}

Analisis credit scoring terhadap status pembayaran kredit barang elektonik dan furniture di PT KB Finansia Multi Finance Tahun 2020 menggunakan metode Bagging K-NN, dengan proporsi 90:10, $m=80 \%$, $C=73$, dan $\mathrm{K}=5$ dapat mengklasifikasikan 10 debitur yang memiliki status pembayaran kredit lancar secara tepat dan juga 2 debitur yang memiliki status pembayaran kredit tidak lancar secara tepat. Sedangkan 1 debitur lainnya tidak tepat diklasifikasikan, dimana debitur seharusnya memiliki status pembayaran kredit lancar namun hasil klasifikasi menunjukkan status pembayaran kredit tidak lancar. Adapun tingkat akurasi yang diperoleh dari hasil analisis credit scoring dengan menggunakan algoritma Bagging K-NN adalah $92,308 \%$. 


\section{DAFTAR PUSTAKA}

[1] A. Siregar and A. Puspabhuana, Data Mining: Pengolahan Data menjadi Informasi dengan RapidMiner, Surakarta: CV Kekata Group, 2017.

[2] E. Prasetyo, Data Mining: Mengolah Data Menjadi Informasi Menggunakan Matlab, Yogyakarta: Andi, 2014.

[3] J. Han and M. Kamber, Data Mining: Concepts and Techniques, San Francisco: Morgan Kaufman Publisher, 2011.

[4] R. S. Wahono and N. Suryana, "Combining Particle Swarm Optimization Based Feature Selection and Bagging Technique for Software Defect Prediction," International Journal of Software Engineering and Its Applications, vol. 7, no. 5, pp. 153-166, 2013.

[5] Y. Y. W., "Perbandingan Performansi Algoritma Decision Tree C5.0, Car, dan Chaid: Kasus Prediksi Status Resiko Kredit di Bank X," in Seminar Nasional Aplikasi Teknologi Informasi, Yogyakarta, 2007.

[6] F. S. Pamungkas, B. D. Prasetya and I. Kharisudin, "Perbandingan Metode Klasifikasi Supervised Learning pada Data Bank Customers Menggunakan Python,” PRISMA Prosiding Seminar Nasional Matematika, pp. 689-694, 2020.

[7] E. Prasetyo, Data Mining: Konsep dan Aplikasi Menggunakan Matlab, Yogyakarta: Andi, 2012.

[8] Suyanto, Machine Learning Tingkat Dasar dan Lanjut, Bandung: Informatika, 2018.

[9] J. Riany, M. Fajar and M. P. Lukman, "Penerapan Deep Sentiment Analysis pada Angket Penilaian Terbuka Menggunakan KNearest Neighbor," Jurnal SISFO, vol. 6, no. 1, pp. 147-156, 2016.

[10] A. M. Mukid, T. Wuryandari, D. Ratnaningrum and R. S. Rahayu, "Bagging Classification Trees untuk Prediksi Resiko Preeklampsia (Studi Kasus: Ibu Hamil Kategori Penerima Jampersal di RSUD Dr. Moewardi Surakarta)," Media Statistika, vol. 8, no. 2, pp. 111-120, 2015.

[11] C. D. Sutton, “Classification and Regression Trees, bagging, and Boosting,” Handbook of Statistics, vol. 24, pp. 303-329, 2005.

[12] R. J. Tibshirani and B. Efron, An Introduction to the Bootstrap, New York: Chapman and Hall, 1993.

[13] Mustafa, "Perancangan Aplikasi Prediksi Kelulusan Tepat Waktu Bagi Mahasiswa Baru dengan Teknik Data Mining (Studi Kasus: Data Akademik Mahasiswa STMIL Dipanegara)," Jurnal Citec, vol. 1, no. 3, 2014.

[14] T. Hestie, R. Tibshirani and J. Friedman, The Elements of Statistical Learning: Data Mining, Inference, and Prediction, New York: Springer-Verlag, 2001.

[15] M. F. Rahman, M. I. Darmawidjadja and D. Alamsah, "Klasifikasi untuk Diagnosa Diabetes Menggunakan Metode Bayesian Regularization Neural Network (RBNN),” Jurnal Informatika, vol. 11, no. 1, pp. 36-45, 2017. 
